\title{
Integrating the soybean-maize-chicken value chains to attain nutritious diets in Tanzania
}

\author{
Wilson Charles Wilson ${ }^{1,2,4}\left(\right.$ - Maja Slingerland ${ }^{1}\left([) \cdot\right.$ Frederick P. Baijukya $^{3} \cdot$ Hannah van Zanten ${ }^{2}(1) \cdot$ \\ Simon Oosting ${ }^{2}$ (D) Ken E. Giller ${ }^{1}(\mathbb{B}$
}

Received: 5 January 2021 / Accepted: 18 August 2021 / Published online: 9 September 2021

(c) The Author(s) 2021

\begin{abstract}
In Tanzania, diets are dominated by starchy staple crops such as maize, levels of malnutrition are high and largely attributed to lack of dietary diversity. We employed fuzzy cognitive mapping to understand the current soybean, maize and chicken value chains, to highlight stakeholder relationships and to identify entry points for value chain integration to support nutritious diets in Tanzania. The fuzzy cognitive maps were constructed based on information gathered during household interviews with 569 farming households, followed by a participatory workshop with 54 stakeholders involved in the three value chains. We found that the soybean, maize and chicken value chains were interconnected, particularly at the level of the smallholder farming systems and at processing facilities. Smallholder farming households were part of one or more value chains. Chicken feed is an important entry point for integrating the three value chains, as maize and soybean meal are the main sources of energy and protein for chicken. Unlike maize, the utilization of soybean in chicken feed is limited, mainly due to inadequate quality of processing of soybean grain into meal. As a result, the soybean grain produced by smallholders is mainly exported to neighbouring countries for further processing, and soybean meal is imported at relatively high prices. Enhancing local sourcing and adequate processing of soybean, coupled with strengthening the integration of smallholder farmers with other soybean, maize and chicken value chain actors offers an important opportunity to improve access to nutritious diets for local people. Our method revealed the importance of interlinkages that integrate the value chains into a network within domestic markets.
\end{abstract}

Keywords Dietary diversity $\cdot$ Food security $\cdot$ SDG $2 \cdot$ Feed $\cdot$ Integrated value chains $\cdot$ Fuzzy cognitive map

\section{Introduction}

Member states of the United Nations pledged their joint support in 2015 for 17 Sustainable Development Goals (SDGs), with the second goal (SDG2) aiming to 'end hunger, achieve food security and improved nutrition and promote sustainable agriculture' by the year 2030 (UN, 2015). Achieving

Wilson Charles Wilson

wilson.wilson@wur.nl

1 Plant Production Systems Group, Wageningen University, 6700 AK, Wageningen, Netherlands

2 Animal Production Systems Group, Wageningen University, $6700 \mathrm{AH}$, Wageningen, Netherlands

3 International Institute of Tropical Agriculture (IITA), P.O. Box 34441, Dar es Salaam, Tanzania

4 Tanzania Livestock Research Institute (TALIRI), Uyole Centre, P.O. Box 6191, Mbeya, Tanzania
SDG2 in sub-Saharan Africa (SSA) is a major challenge, as the rapid human population growth implies that the demand for major cereals will increase three-fold while that of animal-sourced food (ASF) will double by 2050 (Thornton, 2010; van Ittersum et al., 2016). Further, there is a 'missing middle' in terms of the lack of the globally-defined goals and local actions, and particularly a lack of connection between food production and consumption (Veldhuizen et al., 2020). The alarming incidence of food insecurity and undernutrition due to micronutrient deficiency in SSA is associated with limited dietary diversity among households (Rajendran et al., 2017). Tanzania is a typical example of a country facing challenges where limited dietary diversity is common among disadvantaged urban and rural poor households (Alphonce, 2017; Chegere \& Stage, 2020; Wenban-Smith et al., 2016).

In Tanzania, dietary diversity is surprisingly limited in the "breadbasket" regions which are key for food 
production, including Iringa, Njombe, Mbeya and Ruvuma (Altare et al., 2016). The incidence of stunting among the under-five children in these regions is above $38 \%$ against the national prevalence of 35\% (Ministry of Health et al., 2016). Dietary data revealed that the main dishes in these regions have low content of essential micronutrients, vitamins and amino acids that are critical especially in children's diets (Ministry of Health et al., 2016; Temu et al., 2014; Wandel \& Holmboe-Ottesen, 1992). Inadequate diversity in diets is in part related to the high dependence on maize and other carbohydrate-rich staples including rice, sorghum, millet, roots and tubers (cassava, sweet potato and Irish potato), banana and plantain.

Tanzania has set several policies, programs and projects to achieve SDG2 (Alphonce, 2017). Among these, the Agricultural Sector Development Plan phase II (ASDP II 2017-2028) and the Tanzania Livestock Master Plan (TLMP) both target the improvement of livestock productivity and the functioning of the value chains to contribute to improving household income and nutritional security (Michael et al., 2018). Poultry products, both meat and eggs, could contribute to increased dietary diversity. Hence, the TLMP highlights the potential of maize and soybean to provide quality chicken feed, which is a major constraint to expansion of chicken sector production (Andrew et al., 2019; Nandonde et al., 2017). Currently, processed chicken feed is comprised largely of cereal grain/bran (mainly maize), and fish meal (mainly sardines) which could be directly consumed by humans, implying food-feed competition (Mkunda et al., 2020; Tacon \& Metian, 2009). As a result, commercial chicken feed rations are expensive (particularly the protein sources), and contribute about $70 \%$ of the production costs (Mutayoba et al., 2011).

Agricultural diversification with legumes, fruits, vegetables and animal-sourced food (ASF) has significant potential to improve dietary diversity (De Bruyn et al., 2018). The protein from ASF contains the essential amino acids and multiple micronutrients (particularly zinc, iron, vitamin A and B12) in a form readily absorbable in the human body compared with smaller quantities with lower bioavailability in plant-sourced foods (Gibson, 2007; Perignon et al., 2018). These nutrients are particularly important in reducing malnutrition, helping to improve growth and cognitive development of children (Leroy \& Frongillo, 2007). The demand for chicken meat and eggs in Tanzania exceeds domestic production and supply, with average per capita consumption of one egg per week and one chicken per year (MLDF, 2015). With increasing urbanization, economic growth and increasing affluence, the demand for chicken is projected to increase by $148 \%$, while that of beef, goat and mutton, pork and milk will increase by $87 \%, 71 \%, 88 \%, 42 \%$ and $108 \%$, respectively, by 2030 (FAO, 2011).
Between 2014 and 2018, the International Institute of Tropical Agriculture in collaboration with Wageningen University (through the N2Africa Project) and Catholic Relief Services (CRS) (through the Soya ni Pesa Project), promoted soybean production in the Southern Highlands of Tanzania (SH) aiming to improve household nutrition and cash income, and to enhance soil fertility. The increase in soybean production in Tanzania is primarily driven by increasing demand for animal feed, and as a fortifier in human foods under small to medium-scale processing (Martin et al., 2010; Murithi et al., 2014; Wilson, 2018). The utilization of soybean in animal feed has increased and could substitute fish meal which is currently unsustainable in terms of quality and availability. Nevertheless, soybean production, processing and supply cannot meet the current demand. As a result, Tanzania imports soybean meal from India and neighbouring countries (Leonardo et al., 2018; Mbwambo et al., 2016).

To assess the integration of soybean in the maize-based farming systems and its potential inclusion in chicken feed, it is important to understand the functioning of existing value chains. The agri-food value chains incorporate different actors and ranges of activities from initial production, processing and distribution to consumption (Allen $\&$ de Brauw, 2019). Understanding the functioning of the value chains is important since they may interact with each other and/or with other components in a wider food system (Veldhuizen et al., 2020). Attaining dietary diversity requires a value chain framework that incorporate different stakeholders and activities from production to consumption to enhance access to diverse diets (Fanzo et al., 2017; Gelli et al., 2017). The aim of this study was therefore to understand the soybean, maize and chicken value chains, the key stakeholders involved and to identify opportunities and constraints in the functioning of the chains to support diverse diets in the Southern Highlands of Tanzania.

\section{Methodology}

\subsection{Study area}

The present study was conducted in three regions in the Southern Highlands (SH) of Tanzania; Iringa, Njombe and Ruvuma (Fig. 1). The regions are found between latitude $7.7^{\circ} \mathrm{S}$ and longitude and $36^{\circ} \mathrm{E}$. The altitude ranges from $400 \mathrm{~m}$ in the lowlands of Ruvuma region to above $2200 \mathrm{~m}$ asl in the highlands of Iringa and Njombe region, with much of the area at 1600 masl. The mean minimum and maximum temperature is 13 and $22^{\circ} \mathrm{C}$ in the highlands and $22{ }^{\circ} \mathrm{C}$ and $31{ }^{\circ} \mathrm{C}$ in the lowlands (Mhagama, 2020; SAGCOT, 2015). The rainfall pattern is unimodal with mean annual rainfall ranging from $600 \mathrm{~mm}$ in the 


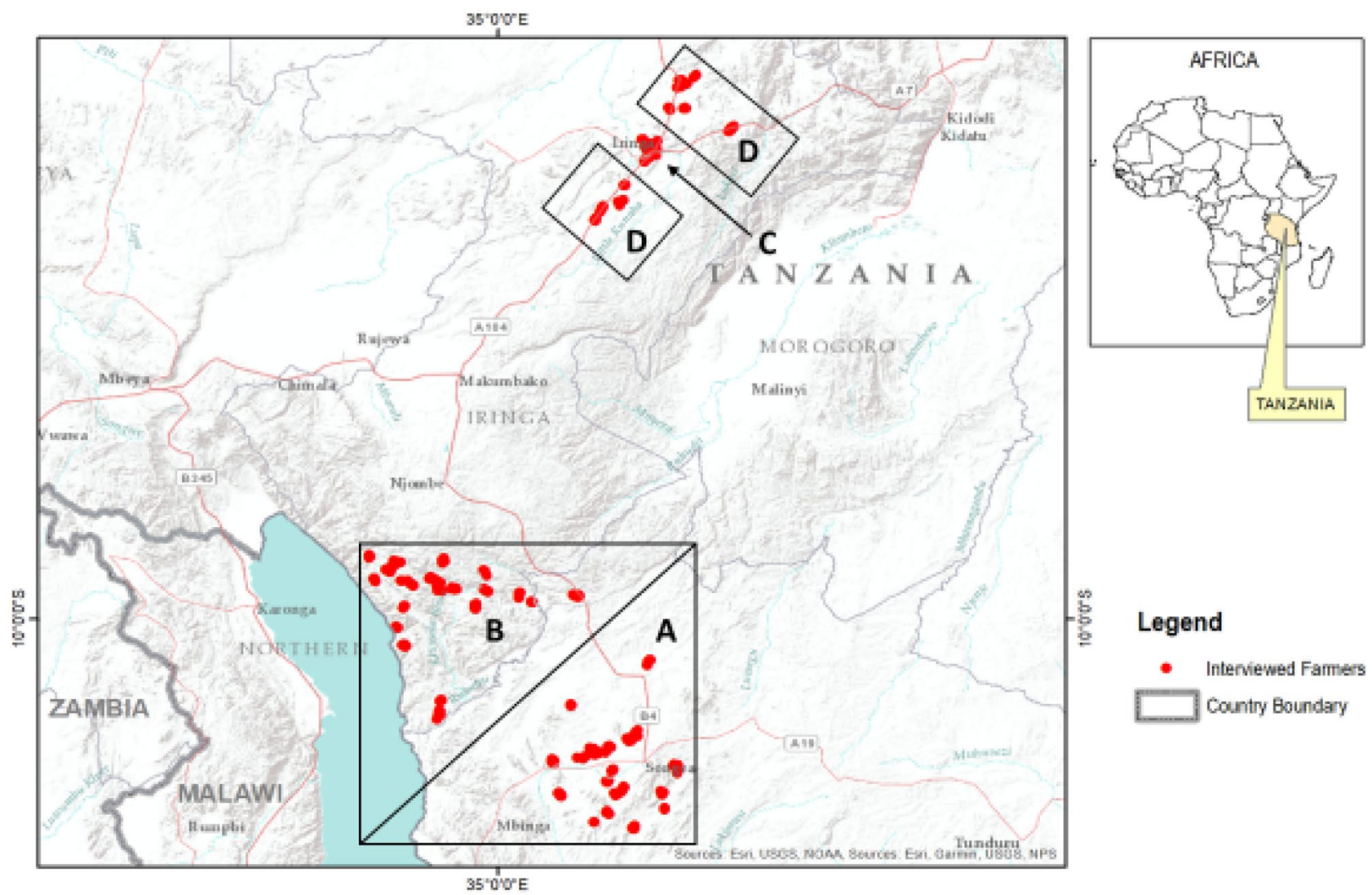

Fig. 1 Location of study regions and three clusters of farmers interviewed in Ruvuma (A), Njombe (B) and Iringa urban (C) and rural (D) regions in the Southern Highlands of Tanzania

lowlands to $2600 \mathrm{~mm}$ in the highlands, starting in November and ending in May, followed by a cooler dry season from June to October. Soils are highly leached and weathered. The regions contribute about $25 \%$ of Tanzania's maize which is mainly produced by smallholder farmers (Suleiman \& Kurt, 2015). Other food crops include wheat, legumes (mainly common bean, chickpeas and soybean), Irish potato, cassava, sunflower, horticultural crops, tea and timber. The main livestock species include traditional and improved chickens (cross-bred dualpurpose, layers and broilers), cattle (beef and dairy), pigs and small ruminants (sheep and goats) (Bisanda et al., 1998; SAGCOT, 2015).

\subsection{Data collection}

To understand the production and value chain development in the current soybean, maize and chicken value chains, we collected secondary and primary data in three steps:

i. Aggregating and analysing secondary data on soybean and maize production and utilization. ii. Collecting and analysing primary data on chicken production and management in urban and rural areas.

iii. Conducting a participatory workshop on value chain mapping and stakeholder analysis in the soybean, maize, chicken value chains.

\subsubsection{Soybean and maize production and utilization}

Data on production and utilization of soybean, were available from a survey conducted in September 2018 which examined production and utilization of soybean among 448 farming households in Ruvuma and Njombe (Baijukya et al., 2019) (Table S1). The data were retrieved from the N2Africa Open Data Kit aggregate platform, sorted, cleaned and analysed. The data on production and productivity of maize was obtained from Tanzania Annual Agriculture Sample Survey 2016/17 (NBS, 2012), (Table S1).

\subsubsection{Characterisation of chicken production systems}

Information on diversity of chicken production systems in urban and rural locations, was obtained from semi-structured interviews with 121 chicken farmers in the Iringa region from November to December 2018. Three administrative 
districts were involved, namely Iringa Municipality with urban farmers and Kilolo and Iringa with rural chicken farmers (Table S2).

\subsubsection{Value chain mapping and stakeholder analysis}

To complement the information from the surveys, we used Fuzzy Cognitive Mapping (FCM) for value chain mapping and stakeholder analysis after pre-testing the approach through a focus group discussion (FGD) with four stakeholders involved in the chicken value chain. FCM is a semiquantitative modelling tool used to structure stakeholder knowledge and views in a diagrammatic format, whereby the system components and relationships between the components are defined based on the stakeholder views and opinions (Jetter \& Kok, 2014; Özesmi \& Özesmi, 2004). The stakeholders involved in the FGD included two livestock extension workers, an animal-feed specialist and an integrated farmer, raising different species of poultry and also engaged in egg collection from other farmers and marketing. During the FGD, the participants were asked to identify the main components constituting the value chain from the point of production to consumption. In a next step, the stakeholders defined the strengths of the causal relationships between the identified components by filling a matrix based on seven categories as applied by Verkerk et al. (2017) i.e. no connection $(0)$ very strong positive $(+++)$, moderate positive $(++)$ or weak positive $(+)$ pointing at the strength of the connections between value chain components; and strong negative (-), moderate negative (-) and weak negative (-) pointing at levels of constraints and weak connections. The exercise took about four hours for the whole process, leading to problems with stakeholder engagement by the end of the session. We therefore adjusted and simplified the methodology and organised a multi-stakeholder workshop with 54 stakeholders involved in the value chains as explained in the next section.

\subsubsection{Multi-stakeholder workshop}

A participatory workshop was organised in May 2019 comprising 54 stakeholder-representatives including farmers, input suppliers, government agencies and non-governmental organisations (NGOs) involved in soybean, maize and chicken value chain development. The objective of the workshop was to map the current soybean, maize and chicken value chains, the stakeholders involved and to identify important entry points for integrating the three value chains.

The stakeholders were divided into three working groups based on their involvement in each value chain, with 21,18 and 16 participants working on soybean, maize and chicken value chains, respectively. The participant groups were first asked to identify the actors involved in the value chain from production to consumption. Next, the stakeholders defined the strengths of the relationships between the identified value chain actors by connecting them on a map using arrows of thickness, relative to their importance in the value chain. The rapporteurs from each group presented the developed value chain and stakeholders involved to all participants for further discussion. Subsequently, each group listed the opportunities and critical constraints limiting the functioning of the value chains, followed by ranking the most important ones. The final exercise was a plenary assessment to identify important entry points for integrating the three value chains for food and feed production based on the expert views and further discussion among all stakeholders.

\subsection{Fuzzy cognitive mapping}

We developed the FCMs based on the primary data collected during the household interviews and a multistakeholder workshop (described in Sect. 2.2.4 above) as well as expert knowledge. In the first step, we grouped the value chain actors into nine (9) classes based on the stakeholders' views during the participatory workshop i.e. (i) producers (smallholders, medium and large scale farmers for maize, soybean and chicken); (ii) agricultural input suppliers; (iii) extension service providers (government and private); (iv) government agencies and regulatory bodies (e.g. seed certification, National Bureau of Standards, Food and Drugs Control Authority, Ministry of Trade (import-export control), policymakers etc.); (v) agricultural research and development organisations (local and international); (vi) marketing and trading agencies (local and export); (vii) processors (medium scale millers, feed processors); (viii) financial institutions; and (ix) consumers (food and feed). The output indicators of the three value chains included household income and access to diverse diets through own-production and purchase.

In Fig. 2, we provide an example of stepwise construction of the FCM for the soybean value chain where we categorised the FCM components into three types of variables i.e. transmitter, receiver and ordinary variables (Gray et al., 2012). The same approach was applied in developing FCMs for the maize and chicken value chains. The transmitter variables are those having a significant influence on the system and affect other variables (and are not affected by other variables), while the receiver variables are affected by other variables but do not affect other variables. The ordinary variables are nodes in between the transmitter and receivers (Gray et al., 2012; Malek, 2017). The FCM component may also act as a central driver especially when its inclusion or exclusion strongly impacts the model (Sperry \& Jetter, 2019). In the current study, the fuzzy cognitive maps were developed by defining the value chain indicators, variables 


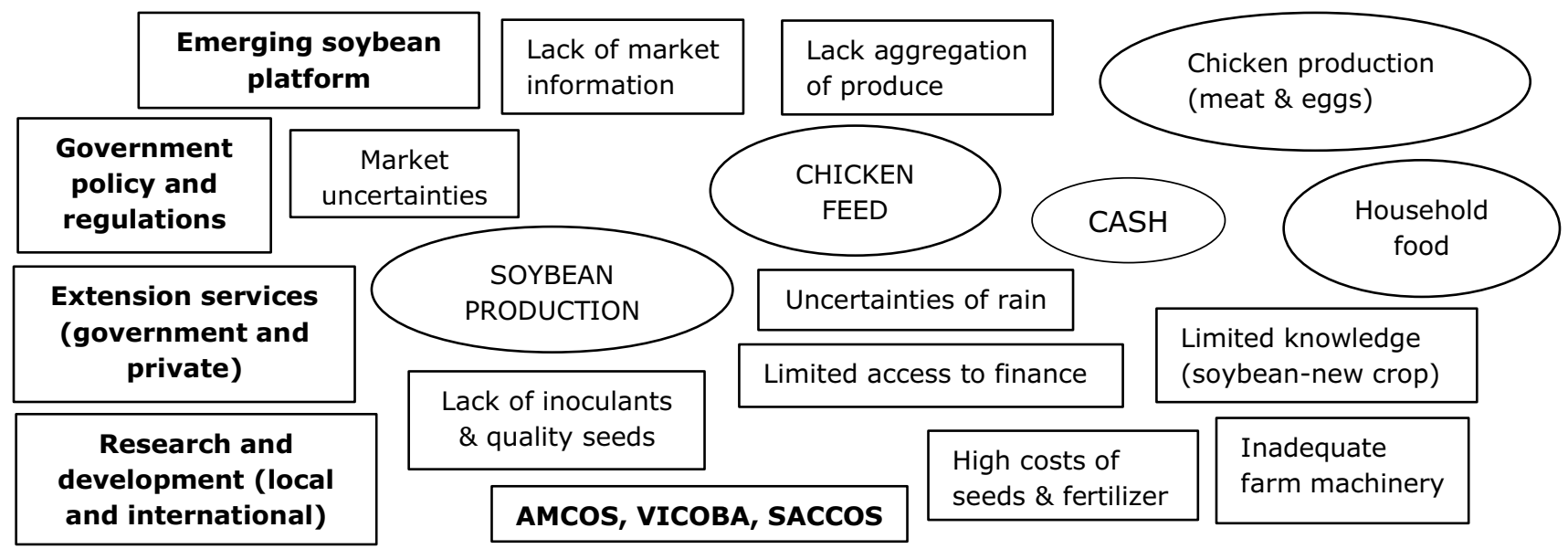

Fig. 2 FCM framework in the case of soybean value chain mapping and stakeholder relationship based on the approach applied by (Murungweni et al., 2011). The steps involved: (A) Defining the indicators in the functioning of the value chain (circles); (B) defining the variables affecting the functioning of the value chain (boxes

and drivers following the protocol by Kokkinos et al. (2018) and Murungweni et al. (2011) based on the following steps:

(i) Defining the indicators of the functioning of the value chains i.e. (a) household production/harvest (soybean, maize and chicken), (b) household food availability (diverse diets), (c) feed availability for the chicken and (d) cash from surplus produce.

(ii) Defining the variables in the functioning of the maize, soybean and chicken value chains based on the constraints identified by the stakeholder groups during the participatory workshop.

(iii) Defining the drivers determining the functioning of the value chains i.e. the presence of research and development initiatives, availability of extension services, government policies, presence of farmer groups/platform, financial institutions and microfinance, market availability (traders, processors and the end users (food and feed).

\subsection{Data analysis}

The quantitative data from the surveys were analysed using Statistical Package for Social Sciences (SPSS) version 25 to obtain the descriptive statistics to find frequencies and mean values that describe the household demographics and socio-economic activities. The significance of the mean differences was assessed using Analysis of Variance (ANOVA) and Chi-square tests. Furthermore, to understand the current maize production and productivity in different regions, we computed means and percentages based on the secondary with plain text); (C) the drivers determining the functioning of the value chain (boxes with bold text). AMCOS stands for Agricultural and Marketing Cooperative Societies while VICOBA and SACCOS stands for Village Community Banks and Savings and Credit Cooperative Societies, respectively

data from the annual agricultural sample survey 2016/17 (National Bureau of Standards 2017).

The qualitative information collected during the interviews, participatory workshop, documentation and experts' views were entered into the online modelling software "Mental Modeller", where FCM graphs were generated based on the pre-defined indicators, variables and drivers following the protocol by Kokkinos et al. (2018) and (Murungweni et al., 2011). The value chain components were linked by attaching weights, where the following aspects were calculated:

i. Total number of value chain components

ii. Total number of connections between the value chain components (positive and negative)

iii. Indegree and outdegree of each value chain component calculated based on the column and row sum of the absolute values of the variables, respectively. The indegree presents the strength of the variables (incoming connections) while the outdegree (out-going connections) is a measure of influence between the variables FCM (Papageorgiou \& Kontogianni, 2012).

iv. Number of connections per value chain component

v. Type of value chain component (transmitter, ordinary or receiver components)

vi. Total number of connections divided by the number of variables

vii. Structural density: number of all identified connections divided by total number of all possible connections between variables in the FCM (Malek, 2017).

viii. Complexity score: the ratio between receiver variables and transmitter variables. 
ix. The centrality of the nodes in the model i.e. the sum of the out-going and incoming connections.

Following the FCM modelling, we developed the graphs with + and - signs indicating the direction of the connections and arrows of different thickness indicating the strength of the connection (Figs. S1-S3), and red fonts indicating negative strength. In the next step we further transformed the developed FCM into simplified diagrams using Microsoft Visio 2010 following the protocol in Sect. 2.4 as depicted in Figs. 4, 5, 6. The numbers in between lines in the developed figs were retrieved from the FCM matrix where the model generates the values between -1 and +1 indicating the strength of the connections between value chain components. We assigned the values into the model based on the constraints and opportunities identified by the stakeholder groups during the participatory workshop using the modified FCM framework applied by Verkerk et al. (2017). In the modified framework, the strength of connection between value chain components were classified into strong positive $(>+0.7)$, moderate/medium $(+0.5$ to +0.7$)$, weak positive $(+0.1$ to +0.4$)$; and strong negative $(>-0.7)$, moderate negative $(-0.5$ to -0.7$)$ and weak negative $(-0.1$ to -0.4$)$ pointing at levels of constraints and weak connections; and zero (no connection).

\section{Results}

\subsection{Crop production and utilization}

Maize is grown by smallholder farmers in the Southern Highlands $(\mathrm{SH})$ for household consumption and sale. According to the Annual Agricultural Sample Survey 2017, the average yield of maize in the SH during the 2016/17 growing season was $1.7 \mathrm{t} / \mathrm{ha}$; slightly above the national average of $1.2 \mathrm{t} / \mathrm{ha}$ (Table S1) (NBS, 2017). In the same period, the SH produced 1.7 million t of maize, contributing to about $30 \%$ and $31 \%$ of the total maize produced and sold in the country, respectively. Based on the N2Africa survey, we found that most households in the $\mathrm{SH}$ grew legumes as a sole crop (81\%) while $19 \%$ intercropped legumes mainly with maize $(95 \%)$ and other crops $(5 \%)$ (Table S1). There was a large variation in the choice of legume produced among households. Of all respondents, $65 \%$ grew legumes, mainly common bean $(41 \%)$ and soybean $(15 \%)$. Other legumes grown were groundnut grown by $25 \%$ of the farmers and cowpea only by one farmer. The average maize production was $1070 \mathrm{~kg}$ per household (range from $54-7000 \mathrm{~kg}$ ). Value addition was mainly done on staple crops whereby $83 \%$ of the respondents milled maize flour locally for household consumption. Soybean was grown as a cash crop, with only $1 \%$ of the respondents reporting that they processed it for food. Other crops were processed in a very small proportion by the households.

\subsection{Characterisation of chicken production systems}

Three systems of chicken production were identified in the study area i.e. extensive, semi-intensive and intensive systems. The extensive system was comprised of indigenous chicken breeds raised under the low input-output system. The intensive systems raised specialized breeds under high input-output systems with commercial broilers, layers and improved dual-purpose crossbreed (mainly Sasso and Kuroiler breeds). Within urban locations, most farmers raised chicken under the intensive system $(75 \%)$, while in rural location chickens were raised under semi-intensive (37\%), free-range production (38\%) and intensive system (49\%) (Table S2). The households interviewed in urban locations raised much larger numbers of chickens, produced more eggs and consumed more ASF than those in rural locations. Some of the farmers produced chicks themselves, while others purchased one-day old chicks from small-scale (local) and/or from large-scale hatcheries and brooders, mainly through selling agents.

\subsection{Chicken feeds and feed ingredients}

The urban farmers fed their chickens on purchased local feed rations/feed ingredients from local stores and market (69\%) and commercial feed (40\%), while those practising freerange and semi-intensive systems relied on a combination of scavenging and kitchen-waste (21\%). On the other hand, chicken farmers in rural locations relied on both locally made feed rations (48\%), scavenging (36\%) and commercial feed rations (22\%). The most common feed ingredients used in chicken feed formulation in the region were maize (grain/ bran) and sunflower seed cake (Fig. 3), mainly sourced from local millers and middlemen at grain market and stores. Fish meal and soybean were also important sources of protein in chicken feed, particularly for the improved chicken breeds.

\subsection{Soybean value chain development and stakeholder's analysis}

Soybean is an emerging crop in the $\mathrm{SH}$, mainly grown as a cash crop for export to the neighbouring countries and for animal feed and small-scale fortified baby food processing. The stakeholders in the soybean value chain identified during the participatory workshop included agricultural input suppliers, smallholder and mid-scale farmers, farmer groups/networks, traders, marketing agents, service providers (machine hiring), extension service providers (government and NGOs), research organization (government and 
Fig. 3 The main ingredients used in locally-made feed rations for different types of chicken based on farmer interviews. $\mathrm{sc}=$ seed cake

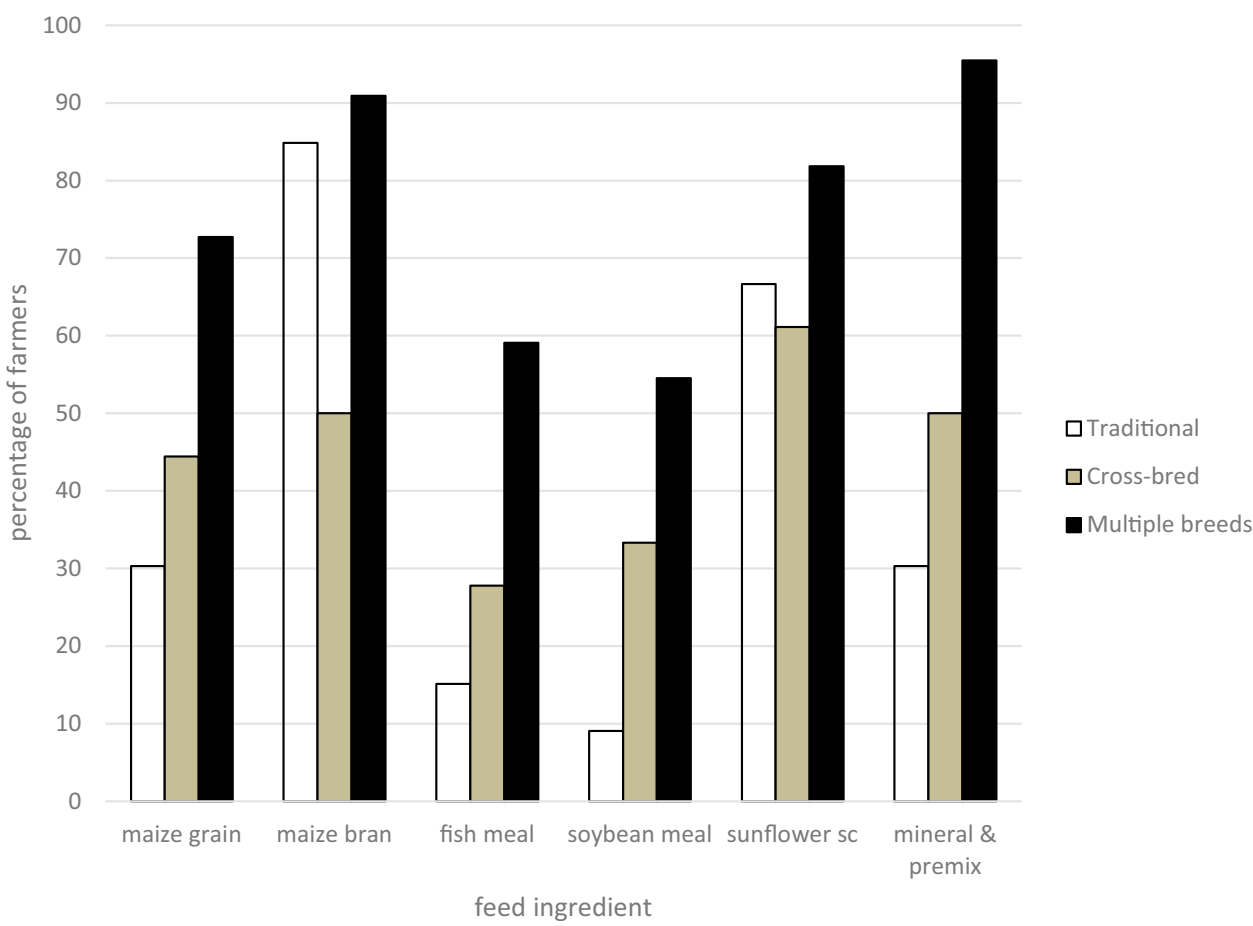

international research organisations), wholesalers, retailers and supermarkets and financial institutions (Fig. S1).

\subsection{Constraints and opportunities in the soybean value chain development}

The soybean value chain was underdeveloped, where we found a negative connection between soybean farmers and processors (with a weak connection of -1), mainly constrained by high uncertainties in the output market $(-1)$ and inadequate processing facilities $(-1)$ in the country (Fig. 4). The uncertainties in the soybean market were mainly associated with lack of market information, weak linkages between producers and buyers, weak farmer organisation and lack of aggregation of the produce. As a result, traders collected soybean from individual farmers in the region. On one hand, soybean farmers complained that there was no market for their produce, while on the other hand traders complained that they could not collect the small amounts of produce from disaggregated farmers. Similar findings were observed during the N2Africa end line survey, where $26.6 \%$ of the interviewed farmers engaged in farmer groups and/or cooperatives.

Other challenges limiting the growth of the soybean value chain included lack of improved quality seeds, limited availability of inoculants, high costs of inputs (quality seeds, fertilizers), inadequate labour-saving technologies (i.e. planters, harvesters, threshers), limited access to finance and lack of awareness of farmers on soybean production as a new crop. The government and private extension service providers contributed to improving awareness of farmers in soybean production. However, there were insufficient extension staff in the region, leading to a medium connection $(+0.6)$ connection between farmers and extension service providers in the FCM (Figs. 4 and S1).

There were strong positive connections $(+1)$ between soybean farmers and NGO's, agricultural research and development institutes (local and international) in the region mainly related to the initiatives in promoting the development of the agricultural sector i.e. the Southern Agricultural Growth Corridor (SAGCOT) initiatives, the N2Africa project and local initiatives on soybean research and dissemination of best-bet technologies to smallholder farmers. Furthermore, the government policy of promoting industrialization has a positive impact on promoting soybean production $(+0.75)$ and processing $(+0.5)$ that could ultimately contribute to the development of the soybean value chain. Nevertheless, soybean was processed locally using mechanical extraction facilities with inadequate processing capacity, resulting in poor quality soybean meal with a large residual oil content. When used in chicken feed formulation this has a negative effect on the growth of chickens leading to a negative relationship between processors and chicken producers $(-0.75)$ and limited extraction of soy oil for household consumption $(-0.5)$. A large quantity of soybean was exported to neighbouring countries for processing, with imports of soybean meal. Chicken farmers preferred the imported soybean meal despite the higher prices due to its good quality compared to the locally processed soybean meal result- 


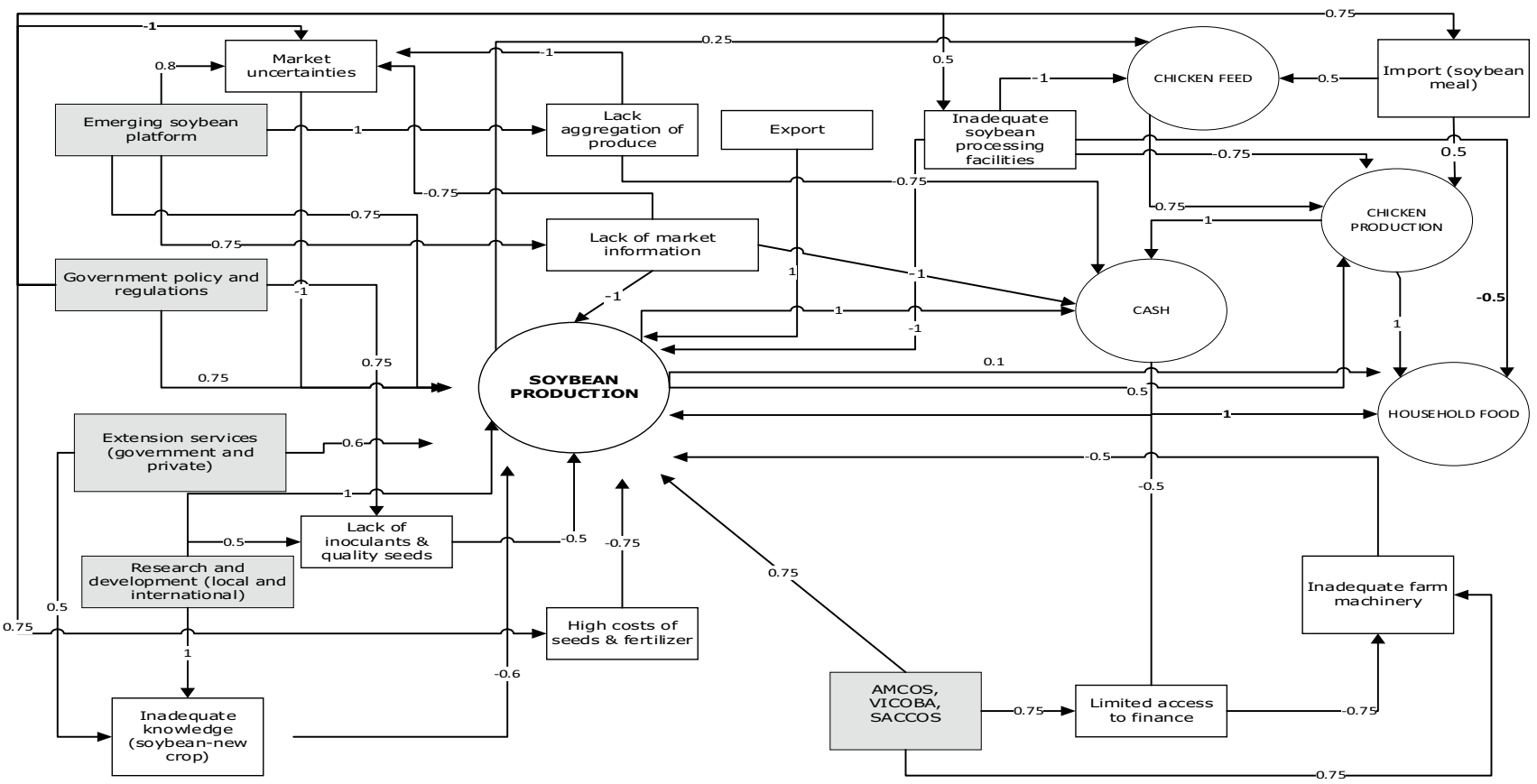

Fig. 4 A Fuzzy Cognitive Map of the soybean value chain in the SH of Tanzania. The white circles are the key indicators of the functioning of the value chain; the grey boxes are value chain drivers and white boxes are variables. AMCOS stands for Agricultural and Marketing Cooperative Societies while VICOBA and SACCOS stands for

ing in medium connections between chicken farmers, feed processors and the import agents $(+0.5)$. Other opportunities for the growth of soybean value chain indicated by the stakeholders during the workshop included: supportive policy environment for private sector investment in soybean production and processing, Value Added Tax (VAT) removal on animal feeds, the existence of Agricultural and Marketing Cooperative Societies (AMCOS), the existence of Village Community Banks (VICOBA), Saving and Credit Cooperative Societies (SACCOS), emerging soybean platform in improving access to input, output market and information and the growing demand for soybean meal as chicken feed.

\subsection{Maize value chain mapping and stakeholder analysis}

Maize was grown as both a food and a cash crop. The surplus produce was traded mainly as dried grain through the informal value chain whereby middlemen were involved in grain collection from the farms and selling on to large grain traders. The grain traders were connected to the consumers through sale of maize grain to the urban market, supply to the grain millers for further processing into various products for consumers within the region and/or export outside of the region (Fig. S2). Some consumers would also access the
Village Community Banks and Savings and Credit Cooperative Societies, respectively. The numbers in between lines (between -1 and +1 ) indicates the strength of the connections between value chain components

maize flour/dehulled maize grain from small-scale processing units (hammer mills) located throughout the region. The mid and large-scale processors produced quality maize products using roller milling machines while following quality standard procedures i.e. sorting, cleaning, milling and packaging. The main products produced by mid and large-scale maize millers included the dehulled maize, white/brown maize flour and fortified flour that was supplied to consumers (within and outside the region) through the distributors selling agents, wholesalers, and retailers. The by-product (maize bran/maize bran with germ) was an important animal feed or ingredient in feed formulation, mainly for chicken. Besides dried corn, sale of green maize cobs was an important source of income for smallholder farmers, particularly those with access to irrigation during the off-season.

\subsection{Constraints and opportunities in maize value chain development}

Despite the significant importance of maize production and supply to neighbouring countries, the maize value chain was poorly coordinated, mainly dominated by middlemen/traders operating in the informal value chain leading to low profitability for producers. There were inadequate storage facilities and warehouse services, contribute to periodic oversupply and low prices of maize in the market 


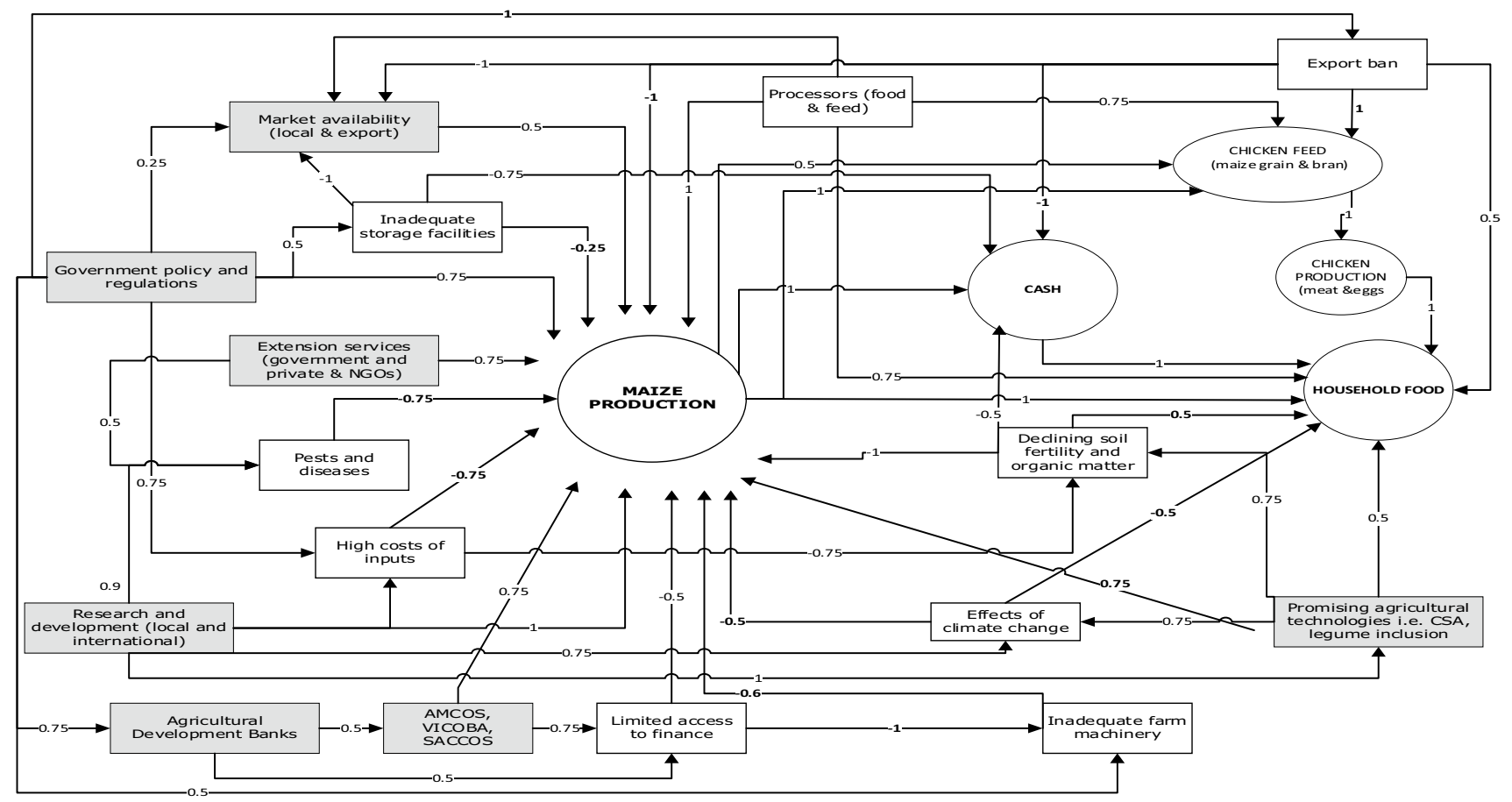

Fig. 5 Fuzzy cognitive map of the maize value chain in the Southern Highlands of Tanzania. The white cycles are the key indicators of the functioning of the value chain; the grey boxes are value chain drivers and white boxes are variables. AMCOS stands for Agricultural and Marketing Cooperative Societies while VICOBA and SACCOS

particularly during the harvesting season (Fig. 5). The functioning of the maize value chain at producer level was mainly constrained by limited access to finances, high costs of inputs, inadequate farm machinery and implements. Other challenges highlighted by stakeholders included the effects of climate change (i.e. changes in annual rainfall patterns and prolonged dry seasons), declining soil fertility and soil organic matter due to continuous maize monocropping with few inputs. In 2017/18 the Tanzanian government banned the export of maize to ensure food security for the citizens, which led to a medium strength to the household food $(+0.5)$ and increased availability of chicken feed $(+1)$. On the other hand, the export ban had negative effects on producers as it led to a decrease in the price of maize and household income (-1).

The increasing demand for maize in the chicken feed industry creates a potential market opportunity leading to a strong connection between maize and chicken farmers $(+1)$. The households producing both maize and chicken can utilize the grains in chicken feed formulation and improve the production of meat and eggs for the household at low cost and obtaining income from surplus produce (+1). Other drivers in the functioning of the current maize value chain included promising agricultural policies and programmes i.e. Agricultural Sector Development stands for Village Community Banks and Savings and Credit Cooperative Societies, respectively. The numbers in between lines (between -1 and +1 ) indicates the strength of the connections between value chain components

Programme (ASDP II), SAGCOT, the establishment of National Food Reserve Agency (NFRA), Tanzania Investment Bank (TIB) and Tanzania Agricultural Development Bank (TADB) as well as the country's industrialization policy in promoting local production and processing. Besides, the existence of agricultural research and development institutes (local and international) and NGOs contributed to the development of the value chain through training and enhanced access to inputs and best-bet technologies and practices aimed at improving maize productivity (e.g. climate-smart agriculture-CSA). Additionally, the initiatives on providing extension services (government and NGOs), contributed to the dissemination of the CSA initiatives $(+1)$.

\subsection{Chicken value chain mapping and stakeholder analysis}

The informal value chain dominated the chicken value chain, whereby chicken farmers could sell live chickens and eggs to middlemen and traders in different channels where various stakeholders are involved (Fig. S3). These include: the households' own-production and consumption, selling live chickens and eggs to neighbours, slaughtered/processed chickens sold to hotels, restaurants and catering services, 
live chickens sold to middlemen/primary market (village level) and ultimately transported to the secondary market (district/municipality). Live chickens from secondary market or mid and large-scale farms, were sold to the informal middleman/agent to process and supply to consumers, hotels, restaurants, catering services, mini supermarkets etc. On the other hand, chickens from secondary markets were either sold to consumers within the region (live chickens/slaughtered) and/or transported from secondary markets to tertiary markets outside the region, mainly Dar es Salaam. The eggs produced on farm were sold to middlemen, selling agents and/or directly sold to markets, local shops, restaurants, and hotels and/or exported to other regions after being collected by traders.

\subsubsection{Constraints and opportunities in the integrated chicken value chain}

During the workshop, stakeholders indicated that limited access to quality feeds and feed ingredients were among the major constraints limiting the development of the chicken sector. Despite having feed processors in the region, the commercial chicken feed ration was expensive and mostly not available in small packages, leading to a weak relationship between smallholder chicken producers and commercial feed processors (+0.25 in Fig. 6). Most smallholder chicken farmers were unable to purchase bulky feed while some farmers under intensive and semi-intensive system partly fed their chicks with commercial feed rations during the early stages of growth and ultimately switched/combined locally made and commercial feed rations to reduce the cost of production.

Soybean meal and fishmeal were the important protein sources used in chicken feed rations by farmers in the $\mathrm{SH}$ regions. Notwithstanding, fishmeal was scarce and expensive. Soybean meal could either be accessed from local processing facilities within the region or through import. The latter option was expensive but mostly preferred by farmers due to the good quality of the imported meal. Imported soybean meal was sold at almost three times the price of whole soybean grain produced in the region. The local soybean meal was produced using mechanical extraction, with inadequate capacity to extrude oil from the grain which limited its value as chicken feed. Other challenges limiting the development of chicken value chain included the inadequate supply of day-old chicks (particularly for broilers and local chickens), lack of market infrastructures and disorganized marketing systems for chickens. Besides, there was a prevalence of chicken diseases mainly associated with limited access to veterinary and extension services, equipment, drugs and vaccines particularly for control of Newcastle disease.

The opportunities envisaged in the chicken value chain included organizing farmers into groups to enhance mass vaccination of chickens, the introduction of small packages of vaccines and drugs for smallholder farmers and

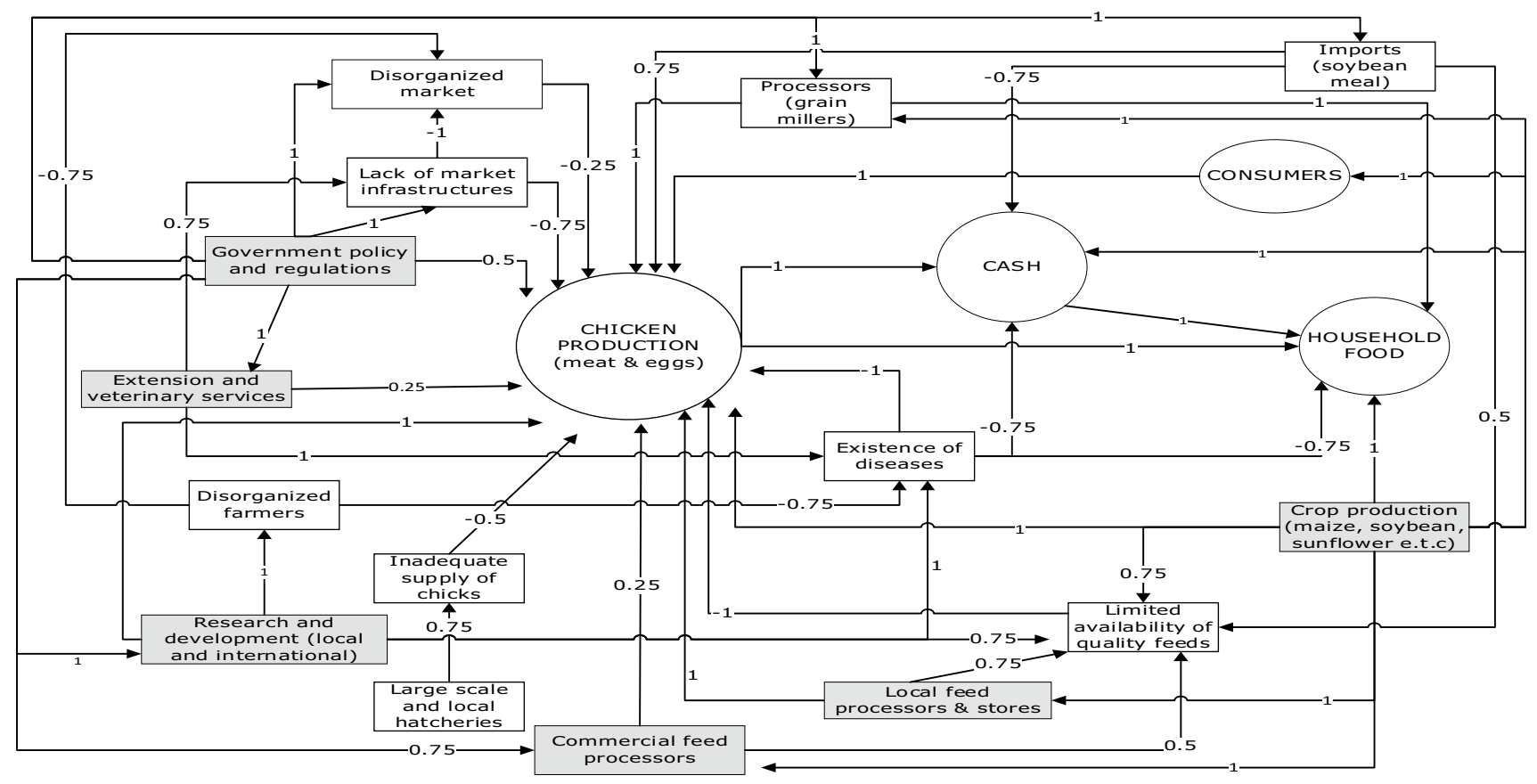

Fig. 6 Fuzzy cognitive map of the chicken value chain in the Southern Highlands of Tanzania. The white cycles are the key indicators of the functioning of the value chain; the grey boxes are value chain drivers and white boxes are variables. The numbers in between lines (between -1 and +1 ) indicates the strength of the connections between value chain components 


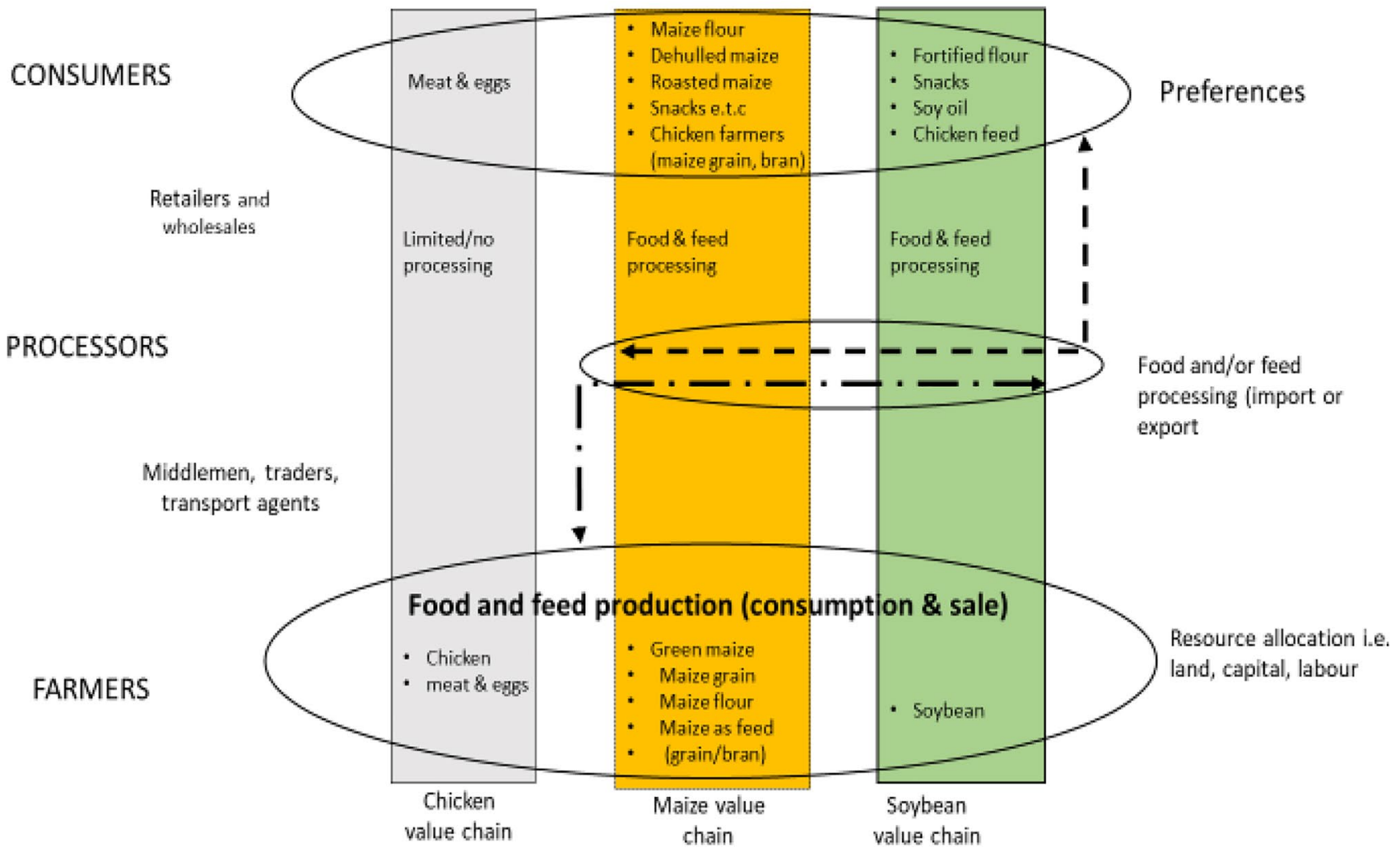

Fig. 7 Key influencers in integrating the soybean-maize-chicken value chains

promoting chicken out-grower schemes. The government, NGOs and international development organisations have significant opportunities to improve chicken production through improved awareness of smallholder farmers on efficient management practices and assisting farmers to organise into groups. Furthermore, the local presence of hatcheries (i.e. Silverlands and Mkuza Chick), and the ongoing chicken projects focusing on genetic improvement including the African Chicken Genetic Gain initiative and the involvement of Hendrix genetics, provided opportunities to improve access to high producing and well-adapted chicken breeds.

\subsection{Integrating the soybean-maize-chicken value chains within the agri-food-feed system}

The stakeholder workshop highlighted that the three value chains were interconnected, particularly at the point of production and of processing (Fig. 7). A smallholder chicken farmer could also be a maize and/or soybean farmer and benefit from own production and consumption of chicken meat and eggs as well as from maize and soybean for home consumption. The maize and soybean farmers would also sell the surplus produce to chicken farmers, mainly through middlemen and selling agents and ultimately being customers of chickens and eggs from chicken farmers. At the farm level, the household has to make decisions on resource allocation (i.e. their land, capital and labour) if they decide to produce soybean, maize and/or chicken. At the processing level, maize and soybean could be processed into diverse food products based on consumer preferences. On the other hand, the animal feed processors could use maize and soybean (the grain or by-products) as energy and protein source in livestock feed formulation, mainly for chicken.

\subsubsection{Value chain integration using the FCM}

Unlike the individual chains, the integrated soybean-maizechicken value chains constituted a network of 29 FCM nodes (ordinary variables) connected by 117 connections, of which $66 \%$ were positive connections (Table 1). Also, the large number of nodes ( 29 nodes) in the integrated value chains indicated a strong connection between the value chain components compared with the individual chains. Using an integrating value chain lens showed that improving access to diverse diets for the household and other consumers was the most important aspect in the functioning of the value chain (receiver component) (Table S3 and Fig. S3). The main drivers in the individual and integrated value chain included the existence of supportive government policies, 
Table 1 Key characteristics of the fuzzy cognitive maps on soybean, maize, chicken and the integrated value chains in the Southern Highlands of Tanzania

\begin{tabular}{lllll}
\hline FCM properties & \multicolumn{2}{l}{ Value chain type } & \\
\cline { 2 - 5 } & $\begin{array}{l}\text { Soybean } \\
\text { value } \\
\text { chain }\end{array}$ & $\begin{array}{l}\text { Maize } \\
\text { value } \\
\text { chain }\end{array}$ & $\begin{array}{l}\text { Chicken } \\
\text { value } \\
\text { chain }\end{array}$ & $\begin{array}{l}\text { Integrated chicken- } \\
\text { soybean-maize value } \\
\text { chains }\end{array}$ \\
\hline Total components & 21 & 22 & 19 & 33 \\
Total connections & 50 & 56 & 53 & 117 \\
Number of positive connections & 30 & 35 & 40 & 77 \\
Number of negative connections & 20 & 21 & 13 & 40 \\
Density & 0.12 & 0.12 & 0.17 & 0.11 \\
Connections per components & 2.33 & 2.55 & 2.80 & 3.55 \\
Number of driver components (influential) & 5 & 3 & 4 & 3 \\
Number of receiver components (dependent) & 1 & 1 & 1 & 1 \\
Number of ordinary components & 15 & 18 & 14 & 29 \\
Complexity score & 0.2 & 0.33 & 0.25 & 0.33
\end{tabular}

research and development organisations contributing to finding solutions to the existing challenges and promoting bestbet agricultural practices, organising farmer into groups, providing agricultural training to smallholder farmers and value chain actors. Another driver to integrate the chains included the existence of large scale and local hatcheries to meet the demand for day-old chicks. When looking at the values of indegree and outdegree in the FCM (Table S3), we can derive a picture of the importance of different value chain components. For instance, the variables with positive indegree and zero outdegree mostly received input from other value chain component "considered as receivers" while the variables with zero in-degree and positive outdegree are considered as senders.

\section{Discussion}

Using FCM, we realize that there are complicated fuzzy networks within and among the components of the three value chains. The analysis provided insights on the opportunities to integrate the three value chains which in turn could contributing to improving access to quality nutrient-dense feed for chickens and ultimately improve access to diverse diets (meat and eggs) for people. To the best of our knowledge, the current study is the first to apply FCM method in value chain mapping based on stakeholder views and opinion. Previous studies applied FCM in modelling agricultural systems and assessing socio-ecological sustainability in agroecosystem (Aravindakshan et al., 2021; Kok, 2009), livelihood vulnerability assessment (Murungweni et al., 2011), climate change adaptation (Verkerk et al., 2017), food security assessment (Aliyev et al., 2017), sustainable food consumption (Morone et al., 2019) and healthy diet assessment (Wang et al., 2016).

The complex networks among value chain components that we identified could be of advantage in terms of value chain robustness, efficiency and smallholder inclusion. Complex networks are likely to be more robust in the face of pressures since there are no dominant buyers in the value chains that can make or break the chain. Also, they could be more efficient as parts of the network consist of shorter value chains, having fewer intermediaries, which may reduce transaction costs (Lee et al., 2012). The networks could also be more inclusive as farmers can choose to enter the network where the value chains fit their capacities. Most studies on value chain analysis have applied a vertical linear framework, focusing on the structured market where there are organised producers, wholesalers, retailers and consumers while addressing the issue related to value chain governance (Gibbon \& Ponte, 2005; Tallontire et al., 2011). Such value chains could be vulnerable as the dominant players can make decisions affecting the functioning of the entire value chain. Vertical value chains often have standards with which smallholders must comply, which may lead to exclusion of specific smallholders (Lee et al., 2012; Tallontire et al., 2011). Furthermore, they also need to connect to large numbers of suppliers which require multiple intermediaries which may affect their efficiency and transaction costs (Lee et al., 2012). Narrow vertical value chains might thus have little relevance for domestic markets within African countries (Gibbon \& Ponte, 2005) and for the type of products produced by smallholders, since most smallholder farmers in SSA sell their produce through different local market outlets.

In the present study, we found that the soybean, maize and chicken value chains are particularly inter-connected at two levels: at the smallholder farming system level and at the level of processing facilities. The production of maize, soybean, chicken can directly contribute to a diverse diet or household income through sale of surplus produce. Smallholder farming households can be producers in one or more value chains (Leonardo et al., 2018) while they could also benefit directly from their own production and consumption. 
On the other hand, the farming household can access diverse diets through the income-food purchase pathway (De Jager et al., 2017), whereby the crop farmers in our case study could access chicken meat and eggs with the cash generated through sales of maize and soybean.

Diversification through legume-cereal intercrop and/ or rotations have significant advantages in improving resource-use efficiency, weed, pest and disease control (Ojiem et al., 2014), and increased yield of subsequent maize in soybean-maize rotations (Rurangwa et al., 2018; Van Vugt et al., 2018). Despite diversification in the farming system, we found that there is a high variation in grain production among households. This variability in crop production reflects the heterogeneity in the socio-economic status of the farming household in terms of land, labour and capital endowments, as well as biophysical factors, whereby the resource-poor farmers are most vulnerable (Van Vugt et al., 2018).

Diversifying diets by including animal sourced foods is an important means to improve growth, development and cognitive responses in young children, particularly during the first 1000 days of life (Stark et al., 2020). In Tanzania, chickens are mostly managed and/or owned by women (De Bruyn et al., 2017; Galiè et al., 2015) who are mainly responsible for household diets (Ochieng et al., 2017). Therefore, improving the productivity of chickens could provide a direct route to improve access to nutritious diets in the household and thus to reducing undernutrition.

Diets may also be improved through other interventions related to maize and legumes. Ongoing initiatives, including the introduction and promotion of Quality Protein Maize (QPM) that has an additional amount of essential amino acids (lysine and tryptophan) (De Groote et al., 2010; Krivanek et al., 2007) may also contribute to higher quality diets for people. The efficient utilization and dissemination of maize flour fortified with soybean could have a significant potential for reducing malnutrition through provision of essential nutrients and vitamins. Furthermore, the efficient utilization of QPM and soybean in chicken feed could reduce the costs of production and ultimately improve chicken productivity to meet the increasing demand for quality eggs and meat (De Groote et al., 2010; Panda et al., 2011).

Diversification in the farming systems is an important indicator of household dietary diversity particularly for poor rural households (Pellegrini \& Tasciotti, 2014; Timler et al., 2020) and have been considered as a coping strategy on the effects of global climate change (McCord et al., 2015). Relying on maize monocropping could have a risk on the household income and food security due to market uncertainties. The export ban in Tanzania in 2016/17 is a vivid example of the risk that farmers could encounter while relying on maize monocropping. Short-term export restrictions of agricultural commodities have been frequently imposed by developing countries in response to price fluctuations and ensuring domestic food supply (Diao \& Kennedy, 2016; Porteous, 2017). Despite the benefits of the export ban in ensuring food security in developing countries, research shows that the rural and urban poor communities are benefited from the decrease in the maize price while at the same time this hurts farmers who rely on growing maize as a cash crop (Diao \& Kennedy, 2016).

The increasing intensification of the chicken sector in Tanzania implies that the demand for major cereals in the animal feed industry will increase. The emerging chicken feed industry is an important entry point for integrating the three value chains, whereby maize (grain/bran) and soybean meal could be used as the main sources of energy and protein for chicken, respectively. The intensification in chicken production implies a greater need for feed resources such as maize and soybean which could also be used for human consumption, implying food-feed competition (Van Zanten et al., 2018). Increasing the resource use efficiency in the current farming systems through sustainable intensification may contribute to reducing the yield gap through increased crop productivity per unit of resource invested (Tittonell \& Giller, 2013) and help to reduce such food-feed competition.

Soybean is mainly grown as a cash crop by smallholders in Tanzania where only few farmers were involved in value addition. Boosting legume production in rural communities might improve access to diverse diets particularly for the rural poor through production followed by own consumption (De Jager et al., 2017). Unlike other grain legumes, soybean is not a staple food, and its utilization requires processing or longer cooking times. Therefore, education on home processing would be required to promote use of soybean to improve food and nutritional security (Khojely et al., 2018). Since soybean is currently grown as a cash crop, its utilization as chicken feed does not raise major issues of food-feed competition.

The emerging animal feed industry is the main driver of soybean demand in Tanzania. Currently, the annual demand for soybean in Tanzania is more than 128,000 $\mathrm{t}$ compared to the current production of about 8,000-10,000 $\mathrm{t}$ (SAGCOT, 2019). Soybean outweighs other plant protein sources due to its high nutritive value in terms of crude protein and energy contents (Medic et al., 2014). Nevertheless, its utilization in chicken feed requires proper processing to reduce the effects of the antinutritional factors and oil content (Dozier et al., 2011; Rada et al., 2017). As a result, most animal feed processors source soybean meal rather than the whole soybean grains due to their limited extrusion capacity and associated high investment costs. In 2019, only three out of forty commercial animal feed processors in Tanzania, registered under Tanzania Animal Feed Manufacturers Association (TAFMA) have solvent extraction with a processing capacity of 6,000 t of soybean per year (SAGCOT, 2019). 
These three animal feed processors include Silverlands Co Ltd, Interchick Co Ltd and Tanfeeds Ltd, located in Iringa, Dar es Salaam and Morogoro, respectively. The latter was the main company processing soybean for sale of soybean meal (and soy oil) while others produced soybean meal for their own use. The recent expansion of solvent extraction facilities at Tanfeed is expected to increase the demand for soybean (SnP, 2015) and might also contribute to meeting the increasing demand for edible oil (Mgeni et al., 2019) and soybean meal required in the chicken feed industry (Mbwambo et al., 2016).

The integration of smallholder farmers with other value chain actors is an important pathway to improving the functioning of the soybean, maize and chicken value chains that might contribute to achieving food security and welfare of the farmers (Kissoly et al., 2017). During the implementation of the N2Africa project, a Soybean Innovation Platform was formed in 2015 to facilitate the dissemination of the latest soybean technologies and practices to smallholder farmers (Odhong, 2018; SnP, 2015). The platform is comprised of the representatives from both public and private sectors i.e. local and international research institutes, district extension officers, village-based agricultural advisors (VBOs), farmer associations and agro-input suppliers and other stakeholders involved in the value chain. While this platform is a means to connect actors within the soybean value chain, similar initiatives may be needed to integrate well with the maize and chicken value chains. Efficient functioning of the integrated value chains requires both public and private sector partners (Bitzer et al., 2013), value chain collaboration (Kissoly et al., 2017) and promoting of innovation platforms (Kilelu et al., 2017). Whereas, most studies to date have explored the integration of smallholder farmers in value chains of export-oriented and high-value cash crops (Barrett et al., 2012; Challies \& Murray, 2011), our study focused on domestic agricultural value chains to reduce the need for imports of soybean meal.

\section{Conclusion}

To meet the increasing demand for nutritious diets in Tanzania, the soybean, maize and chicken value chains all have important roles to play. The emerging chicken feed industry is an important market outlet for smallholders producing maize and soybean in the country providing them with an income to buy nutritious food items. Efficient processing of soybean has a great potential to increase the local availability of soybean both for human food and animal feed. Further, domestic production and processing of soybean is expected to reduce the cost of chicken feed that currently relies on expensive fish meal. To realise the promise of integration of these three value chains, the inefficiencies identified in the soybean chain require effort to strengthen producer groups, to enhance joint marketing of their produce and to enhance private sector investment in appropriate soybean processing facilities.

Supplementary information The online version contains supplementary material available at https://doi.org/10.1007/s12571-021-01213-4.

\section{Declarations}

Conflict of interest The authors declare no conflict of interest.

Open Access This article is licensed under a Creative Commons Attribution 4.0 International License, which permits use, sharing, adaptation, distribution and reproduction in any medium or format, as long as you give appropriate credit to the original author(s) and the source, provide a link to the Creative Commons licence, and indicate if changes were made. The images or other third party material in this article are included in the article's Creative Commons licence, unless indicated otherwise in a credit line to the material. If material is not included in the article's Creative Commons licence and your intended use is not permitted by statutory regulation or exceeds the permitted use, you will need to obtain permission directly from the copyright holder. To view a copy of this licence, visit http://creativecommons.org/licenses/by/4.0/.

\section{References}

Aliyev, E., Rzayeva, I., \& Askerov, N. (2017). Fuzzy cognitive model development for monitoring of results and reporting within the UN FAO food security program. Procedia Computer Science, 120, 430-437.

Allen, S., \& de Brauw, A. (2019). Nutrition-Sensitive Value Chain Development in a Changing Climate. In The Climate-Smart Agriculture Papers (pp. 247-256): Springer.

Alphonce, R. (2017). Ending rural hunger: The case of Tanzania. African Growth Initiative. Global Econonomy and Development Program at Brookings Institution. Washington DC, USA. https:// www.brookings.edu/wp-content/uploads/2017/10/erh-tanzaniacase-study.pdf. Accessed on 12 June 2018.

Altare, C., Delbiso, T. D., Mutwiri, G. M., Kopplow, R., \& Guha-Sapir, D. (2016). Factors associated with stunting among pre-school children in Southern highlands of Tanzania. Journal of Tropical Pediatrics, 62(5), 390-408.

Andrew, R., Makindara, J., Mbaga, S. H., \& Alphonce, R. (2019). Economic viability of newly introduced chicken strains at village level in Tanzania: FARMSIM model simulation approach. Agricultural Systems, 176, 102655.

Aravindakshan, S., Krupnik, T. J., Shahrin, S., Tittonell, P., Siddique, K. H. M., Ditzler, L., et al. (2021). Socio-cognitive constraints and opportunities for sustainable intensification in South Asia: Insights from fuzzy cognitive mapping in coastal Bangladesh. Environment, Development and Sustainability, . https://doi.org/10. 1007/s10668-021-01342-y

Baijukya, F., Omari, M., \& Mzanda, A. (2019). Tanzania Annual Report 2018. Putting nitrogen fixation to work for smallholder farmers in Africa. N2Africa Annual Report. https://n2africa.org/ n2africa-tanzania-annual-report-2018. Accessed on 7 July 2020.

Barrett, C. B., Bachke, M. E., Bellemare, M. F., Michelson, H. C., Narayanan, S., \& Walker, T. F. (2012). Smallholder participation in contract farming: Comparative evidence from five countries. World Development, 40(4), 715-730.

Bisanda, S., Mwangi, W., Verkuijl, H., Moshi, A. J., \& Anandajayasekeram, P. (1998). Adoption of maize production technologies in the Southern 
Highlands of Tanzania.: International Maize and Wheat Improvement Center (CIMMYT), the United Republic of Tanzania and the Southern Africa Centre for Cooperation in Agricultural Research (SACCAR).

Bitzer, V., Glasbergen, P., \& Arts, B. (2013). Exploring the potential of intersectoral partnerships to improve the position of farmers in global agrifood chains: Findings from the coffee sector in Peru. Agriculture and Human Values, 30(1), 5-20.

Challies, E. R., \& Murray, W. E. (2011). The interaction of global value chains and rural livelihoods: The case of smallholder raspberry growers in Chile. Journal of Agrarian Change, 11(1), 29-59.

Chegere, M. J., \& Stage, J. (2020). Agricultural production diversity, dietary diversity and nutritional status: Panel data evidence from Tanzania. World Development, 129, 104856.

De Bruyn, J., Bagnol, B., Darnton-Hill, I., Maulaga, W., Thomson, P. C., \& Alders, R. (2018). Characterising infant and young child feeding practices and the consumption of poultry products in rural Tanzania: A mixed methods approach. Maternal \& child nutrition, 14(2), e12550.

De Bruyn, J., Thomson, P. C., Bagnol, B., Maulaga, W., Rukambile, E., \& Alders, R. G. (2017). The chicken or the egg? Exploring bi-directional associations between Newcastle disease vaccination and village chicken flock size in rural Tanzania. PLoS One, 12(11).

De Groote, H., Gunaratna, N., Ergano, K., \& Friesen, D. (2010). Extension and adoption of biofortified crops: Quality protein maize in East Africa. In Joint 3rd African Association of Agricultural Economists (AAAE) and 48th Agricultural Economists Association of South Africa (AEASA) Conference, Cape Town, (pp. 19-23)

De Jager, I., Abizari, A.-R., Douma, J. C., Giller, K. E., \& Brouwer, I. D. (2017). Grain legume cultivation and children's dietary diversity in smallholder farming households in rural Ghana and Kenya. Food Security, 9(5), 1053-1071.

Diao, X., \& Kennedy, A. (2016). Economywide impact of maize export bans on agricultural growth and household welfare in Tanzania: A Dynamic Computable General Equilibrium Model Analysis. Development Policy Review, 34(1), 101-134.

Dozier, W., Hess, J., \& El-Shemy, H. (2011). Soybean meal quality and analytical techniques (Soybean and nutrition): Janeza Tardine 9, 51000 Rijeka, Croatia.

Fanzo, J. C., Downs, S., Marshall, Q. E., de Pee, S., \& Bloem, M. W. (2017). Value chain focus on food and nutrition security. In Nutrition and health in a developing world (pp. 753-770): Springer.

FAO. (2011). Mapping supply and demand for animal-source foods to 2030. Animal Production and Health Working Paper, 2, 1-154.

Galiè, A., Mulema, A., Benard, M. A. M., Onzere, S. N., \& Colverson, K. E. (2015). Exploring gender perceptions of resource ownership and their implications for food security among rural livestock owners in Tanzania, Ethiopia, and Nicaragua. Agriculture \& Food Security, 4(1), 2.

Gelli, A., Becquey, E., Ganaba, R., Headey, D., Hidrobo, M., Huybregts, L., et al. (2017). Improving diets and nutrition through an integrated poultry value chain and nutrition intervention (SELEVER) in Burkina Faso: Study protocol for a randomized trial. Trials, 18(1), 412.

Gibbon, P., \& Ponte, S. (2005). Trading down: Africa, value chains, and the global economy. Temple University Press.

Gibson, R. S. (2007). The role of diet-and host-related factors in nutrient bioavailability and thus in nutrient-based dietary requirement estimates. Food and Nutrition Bulletin, 28(1_suppl1), S77-S100.

Gray, S., Chan, A., Clark, D., \& Jordan, R. (2012). Modeling the integration of stakeholder knowledge in social-ecological decisionmaking: Benefits and limitations to knowledge diversity. Ecological Modelling, 229, 88-96. https://doi.org/10.1016/j.ecolmodel. 2011.09.011

Jetter, A. J., \& Kok, K. (2014). Fuzzy Cognitive Maps for futures studies-A methodological assessment of concepts and methods. Futures, 61, 45-57.
Khojely, D. M., Ibrahim, S. E., Sapey, E., \& Han, T. (2018). History, current status, and prospects of soybean production and research in sub-Saharan Africa. The Crop Journal, 6(3), 226-235.

Kilelu, C., Klerkx, L., Omore, A., Baltenweck, I., Leeuwis, C., \& Githinji, J. (2017). Value chain upgrading and the inclusion of smallholders in markets: Reflections on contributions of multistakeholder processes in dairy development in Tanzania. The European Journal of Development Research, 29(5), 1102-1121.

Kissoly, L., Faße, A., \& Grote, U. (2017). The integration of smallholders in agricultural value chain activities and food security: Evidence from rural Tanzania. Food Security, 9(6), 1219-1235.

Kok, K. (2009). The potential of Fuzzy Cognitive Maps for semiquantitative scenario development, with an example from Brazil. Global Environmental Change, 19(1), 122-133.

Kokkinos, K., Lakioti, E., Papageorgiou, E., Moustakas, K., \& Karayannis, V. (2018). Fuzzy cognitive map-based modeling of social acceptance to overcome uncertainties in establishing waste biorefinery facilities. Frontiers in Energy Research, 6, 112.

Krivanek, A. F., De Groote, H., Gunaratna, N. S., Diallo, A., \& Friesen, D. (2007). Breeding and disseminating quality protein maize (QPM) for Africa. African Journal of Biotechnology, 6(4), 312-324.

Lee, J., Gereffi, G., \& Beauvais, J. (2012). Global value chains and agrifood standards: Challenges and possibilities for smallholders in developing countries. Proceedings of the National Academy of Sciences, 109(31), 12326-12331.

Leonardo, W., van de Ven, G. W., Kanellopoulos, A., \& Giller, K. E. (2018). Can farming provide a way out of poverty for smallholder farmers in central Mozambique? Agricultural Systems, 165, 240-251.

Leroy, J. L., \& Frongillo, E. A. (2007). Can interventions to promote animal production ameliorate undernutrition? The Journal of Nutrition, 137(10), 2311-2316.

Malek, Ž. (2017). Fuzzy-logic cognitive mapping: Introduction and overview of the method. In Environmental Modeling with Stakeholders (pp. 127-143): Springer.

Martin, H., Laswai, H., \& Kulwa, K. (2010). Nutrient content and acceptability of soybean based complementary food. African Journal of Food, Agriculture, Nutrition and Development, 10(1).

Mbwambo, N., Nandonde, S., Ndomba, C., \& Desta, S. (2016). Assessment of animal feed resources in Tanzania. Tanzania Ministry of Agriculture, Livestock and Fisheries and International Livestock Research Institute (ILRI). Nairobi, Kenya.

McCord, P. F., Cox, M., Schmitt-Harsh, M., \& Evans, T. (2015). Crop diversification as a smallholder livelihood strategy within semiarid agricultural systems near Mount Kenya. Land Use Policy, $42,738-750$.

Medic, J., Atkinson, C., \& Hurburgh, C. R. (2014). Current knowledge in soybean composition. Journal of the American Oil Chemists' Society, 91(3), 363-384.

Mgeni, C. P., Müller, K., \& Sieber, S. (2019). Tariff impact on industrialization in Tanzania: Evidence from edible oil sub-sector. Journal of Economics and Sustainable Development, 10, 15-30.

Mhagama, M. L. (2020). Vulnerability and resilience of dry land irrigation farming schemes against climate change: A case of Ruvuma Basin. Universität Vechta, Vechta, Germany.

Michael, S., Mbwambo, N., Mruttu, H., Dotto, M., Ndomba, C., Silva, M. d., et al. (2018). Tanzania livestock master plan. Nairobi, Kenya: ILRI. https://www.ilri.org/publications/tanzania-livestockmaster-plan. Accessed on 17th March 2020.

Ministry of Health, C. D., Gender, Elderly Children - MoHCDGEC/ Tanzania Mainland, Ministry of Health - MoH/Zanzibar, National Bureau of Statistics - NBS/Tanzania, Office of Chief Government 
Statistician - OCGS/Zanzibar, \& ICF (2016). Tanzania Demographic and Health Survey and Malaria Indicator Survey 20152016. Dar es Salaam, Tanzania: MoHCDGEC, MoH, NBS, OCGS, and ICF.

Mkunda, J. J., Lassen, J., Chachage, B., Kusiluka, L. J., \& Pasape, L. (2020). Analysis of marketing efficiency of processed sardine products of Lake Victoria: Case of Tanzania. African Journal of Science, Technology, Innovation and Development, 12(1), 85-96.

MLDF. (2015). Tanzania livestock modenization initiative. Dar es Salaam, Tanzania: Ministry of Livestock Development and Fisheries. https://hdl.handle.net/10568/67749.

Morone, P., Falcone, P. M., \& Lopolito, A. (2019). How to promote a new and sustainable food consumption model: A fuzzy cognitive map study. Journal of Cleaner Production, 208, 563-574.

Murithi, H., Beed, F., \& Kijoji, A. (2014). Integrated pest management (IPM) of soybean: International Institute of Tropical Agriculture. Ibadan, Nigeria.

Murungweni, C., Van Wijk, M. T., Andersson, J. A., Smaling, E. M., \& Giller, K. E. (2011). Application of fuzzy cognitive mapping in livelihood vulnerability analysis. Ecology and Society, 16(4).

Mutayoba, S., Dierenfeld, E., Mercedes, V., Frances, Y., \& Knight, C. (2011). Determination of chemical composition and anti-nutritive components for Tanzanian locally available poultry feed ingredients. International Journal of Poultry Science, 10(5), 350-357.

Nandonde, S., Nigussie, K., \& Stapleton, J. (2017). Feed priorities in the Tanzania livestock master plan. Nairobi, Kenya: International Livestock Research Institute. Source: https://hdl.handle. net/10568/89062.

NBS. (2012). Tanzania Regional Profiles. National Bureau of Statistics. The United Republic of Tanzania. Dar es Salaam, Tanzania. Source: https://www.nbs.go.tz/index.php/en/regional-profiles.

NBS. (2017). National Bureau of Statistics. Annual agriculture sample survey. Crop and Livestock report. The United Republic of Tanzania. Dar es Salaam, Tanzania. Source: https://nbs.go.tz/nbs/takwimu/ Agriculture/2016_17_AASS_\%20report.pdf.

Ochieng, J., Afari-Sefa, V., Lukumay, P. J., \& Dubois, T. (2017). Determinants of dietary diversity and the potential role of men in improving household nutrition in Tanzania. PLoS One, 12(12).

Odhong, J. (2018). Photo report: Africa RISING-Feed the Future SI innovation lab joint field visit to Tanzania. Ibadan, Nigeria: International Institute of Tropical Agriculture (IITA). Link: https://hdl. handle.net/10568/93070.

Ojiem, J., Franke, A., Vanlauwe, B., De Ridder, N., \& Giller, K. E. (2014). Benefits of legume-maize rotations: Assessing the impact of diversity on the productivity of smallholders in Western Kenya. Field Crops Research, 168, 75-85.

Özesmi, U., \& Özesmi, S. L. (2004). Ecological models based on people's knowledge: A multi-step fuzzy cognitive mapping approach. Ecological Modelling, 176(1-2), 43-64

Panda, A., Raju, M., Rao, S. R., Lavanya, G., Reddy, E. P. K., \& Sunder, G. S. (2011). Nutritional evaluation and utilisation of quality protein maize, Nityashree hybrid maize, and normal maize in broiler chickens. British Poultry Science, 52(5), 632-638.

Papageorgiou, E., \& Kontogianni, A. (2012). Using fuzzy cognitive mapping in environmental decision making and management: a methodological primer and an application. International Perspectives on Global Environmental Change, 427-450.

Pellegrini, L., \& Tasciotti, L. (2014). Crop diversification, dietary diversity and agricultural income: Empirical evidence from eight developing countries. Canadian Journal of Development Studies/ revue Canadienne D'études Du Développement, 35(2), 211-227.

Perignon, M., Barre, T., Gazan, R., Amiot, M.-J., \& Darmon, N. (2018). The bioavailability of iron, zinc, protein and vitamin A is highly variable in French individual diets: Impact on nutrient inadequacy assessment and relation with the animal-to-plant ratio of diets. Food Chemistry, 238, 73-81.
Porteous, O. (2017). Empirical effects of short-term export bans: The case of African maize. Food Policy, 71, 17-26.

Rada, V., Lichovnikova, M., \& Safarik, I. (2017). The effect of soybean meal replacement with raw full-fat soybean in diets for broiler chickens. Journal of Applied Animal Research, 45(1), 112-117.

Rajendran, S., Afari-Sefa, V., Shee, A., Bocher, T., Bekunda, M., \& Lukumay, P. J. (2017). Does crop diversity contribute to dietary diversity? Evidence from integration of vegetables into maizebased farming systems. Agriculture \& Food Security, 6(1), 50.

Rurangwa, E., Vanlauwe, B., \& Giller, K. E. (2018). Benefits of inoculation, $\mathrm{P}$ fertilizer and manure on yields of common bean and soybean also increase yield of subsequent maize. Agriculture, Ecosystems \& Environment, 261, 219-229.

SAGCOT. (2015). Southern Agricultural Growth Corridor of Tanzania. SAGCOT IHEMI Cluster Development Framework. Source: http:// sagcot.co.tz/index.php/ihemi-cluster/. Accessed on 17 December 2020.

SAGCOT. (2019). Realizing the protein crop: How soya can transform the animal feeds sub sector in Tanzania. Source: https:// sagcotctf.co.tz/wp-content/uploads/2019/10/FIT4AG-SOYAVALIDATION-REPORT.pdf. Accessed on 24 February 2020.

SnP. (2015). Soya ni Pesa. Steady progress in building the soybean sector in Tanzania. Catholic Relief Services (CRS). Retrived on March 17th 2020. Website: https://ndo.or.tz/wp-content/uploads/ 2015/05/Soya-ni-Pesa-Newsletter-Issue-3-1.pdf.

Sperry, R. C., \& Jetter, A. J. (2019). A Systems Approach to Project Stakeholder Management: Fuzzy Cognitive Map Modeling. Project Management Journal, 50(6), 699-715.

Stark, H., Omer, A., Wereme N'Diaye, A., Sapp, A. C., Moore, E. V., \& McKune, S. L. (2020). The Un Oeuf study: Design, methods and baseline data from a cluster randomised controlled trial to increase child egg consumption in Burkina Faso. Maternal \& child nutrition, e13069.

Suleiman, R. A., \& Kurt, R. A. (2015). Current maize production, postharvest losses and the risk of mycotoxins contamination in Tanzania. In 2015 ASABE Annual International Meeting, (pp. 1): American Society of Agricultural and Biological Engineers.

Tacon, A. G., \& Metian, M. (2009). Fishing for feed or fishing for food: increasing global competition for small pelagic forage fish. Ambio, 294-302.

Tallontire, A., Opondo, M., Nelson, V., \& Martin, A. (2011). Beyond the vertical? Using value chains and governance as a framework to analyse private standards initiatives in agri-food chains. Agriculture and Human Values, 28(3), 427-441.

Temu, A., Waized, B., Ndyetabula, D., Robinson, E., Humphrey, J., \& Henson, S. (2014). Mapping value chains for nutrient-dense foods in Tanzania (No. IDS Evidence Report; 76). IDS.

Thornton, P. K. (2010). Livestock production: Recent trends, future prospects. Philosophical Transactions of the Royal Society of London B: Biological Sciences, 365(1554), 2853-2867.

Timler, C., Alvarez, S., DeClerck, F., Remans, R., Raneri, J., Carmona, N. E., et al. (2020). Exploring solution spaces for nutrition-sensitive agriculture in Kenya and Vietnam. Agricultural Systems, 180, 102774.

Tittonell, P., \& Giller, K. E. (2013). When yield gaps are poverty traps: The paradigm of ecological intensification in African smallholder agriculture. Field Crops Research, 143, 76-90. https://doi.org/10. 1016/j.fcr.2012.10.007

UN. (2015). United Nations. Transforming our world: The 2030 Agenda for Sustainable Development. General Assembley 70 session.

Van Ittersum, M. K., Van Bussel, L. G., Wolf, J., Grassini, P., Van Wart, J., Guilpart, N., et al. (2016). Can sub-Saharan Africa feed itself? Proceedings of the National Academy of Sciences, 113(52), 14964-14969.

Van Vugt, D., Franke, A., \& Giller, K. (2018). Understanding variability in the benefits of $\mathrm{N} 2$-fixation in soybean-maize rotations 
on smallholder farmers' fields in Malawi. Agriculture, Ecosystems \& Environment, 261, 241-250.

Van Zanten, H. H., Herrero, M., Van Hal, O., Röös, E., Muller, A., Garnett, T., et al. (2018). Defining a land boundary for sustainable livestock consumption. Global Change Biology, 24(9), 4185-4194.

Veldhuizen, L. J., Giller, K. E., Oosterveer, P., Brouwer, I. D., Janssen, S., van Zanten, H. H., et al. (2020). The Missing Middle: Connected action on agriculture and nutrition across global, national and local levels to achieve Sustainable Development Goal 2. Global Food Security, 24, 100336.

Verkerk, P. J., Sánchez, A., Libbrecht, S., Broekman, A., Bruggeman, A., Daly-Hassen, H., et al. (2017). A participatory approach for adapting river basins to climate change. Water, 9(12), 958 .

Wandel, M., \& Holmboe-Ottesen, G. (1992). Food availability and nutrition in a seasonal perspective: A study from the Rukwa region in Tanzania. Human Ecology, 20(1), 89-107.

Wang, M.-H., Kurozumi, K., Kawaguchi, M., Lee, C.-S., Tsuji, H., \& Tsumoto, S. (2016). Healthy diet assessment mechanism based on fuzzy markup language for Japanese food. Soft Computing, 20(1), 359-376.

Wenban-Smith, H., Faße, A., \& Grote, U. (2016). Food security in Tanzania: the challenge of rapid urbanisation. [journal article]. Food security, 8(5), 973-984, doi:https://doi.org/10.1007/ s12571-016-0612-8.

Wilson, R. (2018). Household, Small and Medium Scale Processing of Soya Bean (Glycine max) in Tanzania. Adv Food Process Technol: AFPT-115. DOI, 10.

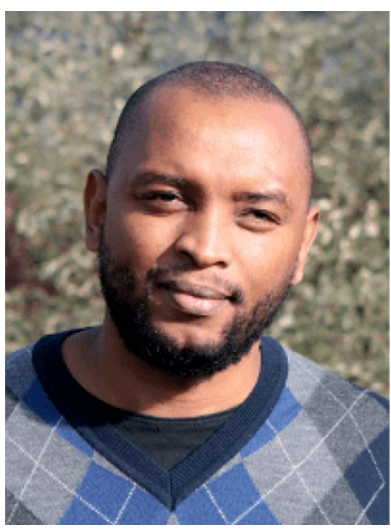

Wilson Charles Wilson is a $\mathrm{PhD}$ candidate at Plant Production and Animal Production Systems Group, Wageningen University and hosted by the International Institute of Tropical Agriculture (IITA). He started his PhD research in 2018 after obtaining his MSc in Animal Sciences from Wageningen University where he specialized in Global and Sustainable Production. His current research focuses on exploring the potential of integrating the maize-soybeanchicken value chains in sustaining diverse diets and assessing their contribution to achieving the Sustainable Development Goals (SDGs), SDG 2 in particular (Zero hunger) in Tanzania. The research is part of the "The Missing Middle project: Food system transformation pathways to link actions at multiple levels to Sustainable Development Goals (SDGs) particularly the SDG 2, 12, 13 and 15 in Tanzania and Vietnam" funded by NWO-WOTRO research program.

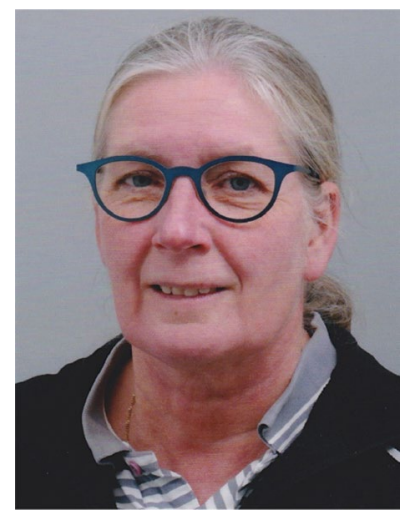

Maja Slingerland is Associate Professor in Plant Production Systems at Wageningen University. She has always focused her research on smallholder crop and livestock producers who manage their resources to achieve livelihood objectives such as income and food security in Sub Saharan Africa. Since about 10 years she investigates the interface between smallholders and value chains, looking at terms of engagement, certification and service delivery in the oil palm and cocoa sector. She does research on smallholders as participants in a variety of value chains simultaneously. Over time, her research developed from food to food and nutrition security, from income to living income and from supply chains to food systems. She worked and lived for ten years in SSA before being permanently employed by Wageningen university.

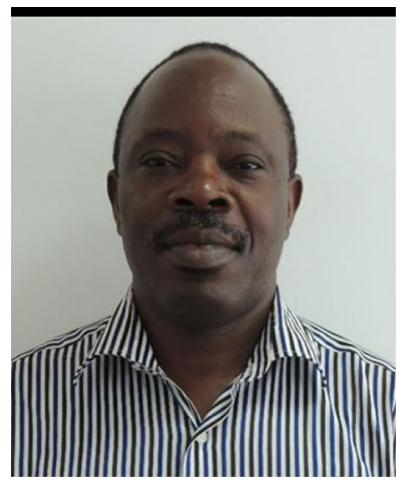

Frederick Baijukya is Farming System Scientist at International Institute of Tropical Agriculture (IITA) based in Dar es Salaam Tanzania. Formerly, he was Agronomist at Intentional Centre of Tropical Agriculture (CIAT), Nairobi office, and before that, he served as Principal Agricultural Research Officer in the Department of Research and Development, Ministry of Agriculture and Cooperative, Tanzania. $\mathrm{He}$ has worked extensively in different farming systems in East Africa with special focus on intensification and diversification of smallholder- agricultural systems, participating in different projects including 'Transboundary Agroecosystems Management of Kagera Basin (TAMP)'; 'Exploring trade-offs around farming livelihoods and the environment: the AfricaNUANCES framework; 'Putting nitrogen fixation to work for smallholder farmers in sub-Saharan Africa (N2Africa) and Africa Cassava Agronomy Initiatives (ACAI).

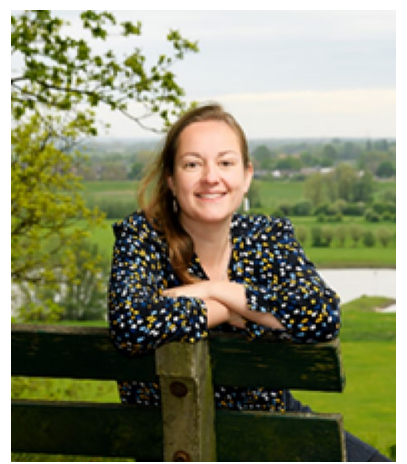

Dr. Hannah van Zanten is Assistant Professor at the Wageningen University Farming Systems Ecology group. It is her ambition to unravel how circular food systems can contribute to producing healthy foods for a growing population within the carrying capacity of the Earth. Hannah graduated cum laude from Wageningen University in 2009 with a master's degree in Animal Sciences. Her $\mathrm{PhD}$ project at the Animal Production Systems group focused on the environmental benefits of using human-inedible-sources as livestock feed. Her research shows that 
farm animals reared under a circular paradigm can play a crucial role in feeding humanity, while reducing the environmental impact.

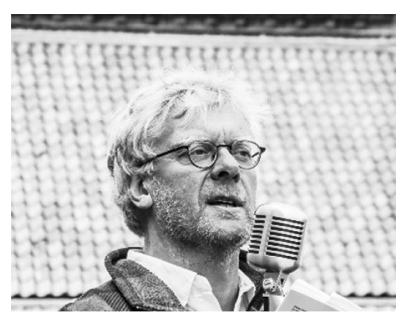

Simon Oosting is associate professor at the Animal Production Systems group of Wageningen University, Wageningen The Netherlands. His field of research is Livestock Production Systems in the tropics. Research topics cover issues such as the effects of market quality of livestock farming system development, trade-offs between contributions to food security, circularity and environmental performance of livestock systems, and multi-functionality of livestock in smallholder farming systems.

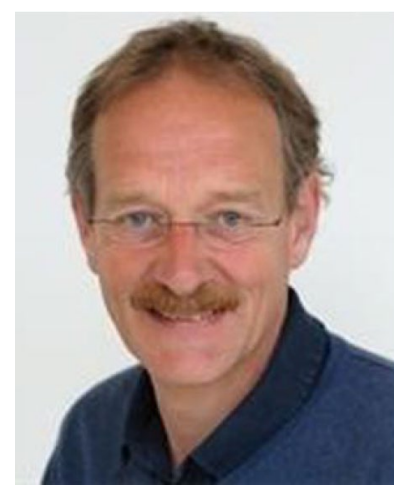

Ken E. Giller is Professor of Plant Production Systems at Wageningen University. He leads a group of scientists with pro-found experience in (farming) systems analysis and exploring future scenarios of change. Ken's research has focused on small-holder farming systems in sub-Saharan Africa, and in particular problems of soil fertility and the role of nitrogen fixation in tropi-cal legumes. He is author of the book "Nitrogen Fixation in Tropical Cropping Systems". Ken joined Wageningen University in 2001 after holding professorships at Wye College, University of London, and the University of Zimbabwe. 